\title{
PENERAPAN MODEL PROBLEM BASED LEARNING (PBL) \\ DALAM PEMBELAJARAN IPS DI SEKOLAH
}

\author{
Risma Hartati \\ STKIP Riama Medan \\ Email : rismahartati25@gmail.com
}

\begin{abstract}
ABSTRAK
Guru masa kini harus mumpuni dan mampu bersaing secara global. Persaingan global menantang guru lebih kompetitif, berpikir sistematis, logis dan konsisten serta dapat bekerja sama. Salah satu model pembelajaran yang dapat diterapkan pada pembelajaran IPS di sekolah adalah Model pembelajaran Problem Based Learning. Melalui penerapan model Problem Based Learning dalam Pembelajaran IPS menjadi salah satu pembelajaran berbasis inovasi dan karakter budaya bangsa yang perlu digugu. Pada dasarnya model memberikan penekanan pada penanaman norma, nilai dan karakter sosial budaya bangsa pada diri peserta didik. Model Pembelajaran Problem Based Learning (PBL) menjadi salah satu solusi untuk dapat memberikan tingkat penguasaan dan kemampuan berpikiri kritis peserta didik.
\end{abstract}

Kata kunci: model problem based learning, pembelajaran IPS

\begin{abstract}
Today's teachers must be qualified and able to compete globally. Global competition challenges teachers to be more competitive, think systematically, logically and consistently and can work together. One of the learning models that can be applied to social studies learning in schools is the Problem Based Learning model. Through the application of the Problem Based Learning model in Social Studies learning, it is one of the innovation-based learning and the character of the nation's culture that needs to be nurtured. Basically the model emphasizes the inculcation of norms, values and the nation's socio-cultural character in students. Learning Model Problem Based Learning (PBL) is one solution to be able to provide the level of mastery and critical thinking skills of students.
\end{abstract}

Keywords: problem based learning model, social studies learning 
PENDAHULUAN

Dengan meningkatnya arus informasi saat ini seiring dengan kemajuan ilmu pengetahuan dan teknologi berdampak langsung terhadap seluruh aspek kehidupan termasuk pendidikan. Pendidikan menjadi ranah penting bagi kemajuan suatu bangsa. Suatu bangsa dikatakan maju adalah bangsa yang pendidikannya berjalan dengan baik. Melalui pendidikan yang baik, tentunya akan melahirkan sumber daya manusia yang baik pula. Suatu negara dengan sumber daya alam yang melimpah tanpa dibarengi dengan sumber daya manusia yang mampu mengelola kekayaan alamnya dengan baik, maka kesejahteraan dan kemajian bagi negaranya tidak akan terwujud. Pendidikan seyogianya berperan sangat penting dalam membentuk sumber daya manusia yang terampil, kreatif dan inovatif. Pendidikan juga berfungsi mengembangkan kecerdasan berpikir individu secara emosional dan keteramplan untuk hidup, menyesuaikan diri di tengah lingkungan dengan baik dan penuh tanggung jawab.
Demi terwujudnya tujuan mulia pendidikan nasional diperlukan suatu pendidikan yang berkualitas. Prioritas utama dari pendidkan yang berkualitas tidak terlepas dari kegiatan proses belajar mengajar, namun juga memberikan kemampuan dalam berpikir kritis pada peserta didik. Berpikir kritis merupakan suatu keharusan dalam upaya menyelesaikan masalah, membuat keputusan, menganalisis asumsiasumsi. Berpikir kritis sudah seharusnya diterapkan sedini mungkin kepada peserta didik untuk belajar memecahkan masalah secara sistematis, inovatif dan mendesain solusi yang mendasar (Pritasari, 2011). Sekolah maupun perguruan tinggi sebagai suatu lembaga pendidikan formal merupakan tempat peserta didik mengembangkan berbagai macam kemampuan diri secara individu maupun sosial untuk memberi bekal dan keterampilan hidup menyesuaikan diri dengan lingkungannya kelak, namun berdasarkan hasil observasi, saat ini kemampuan berpikir siswa maupun masih rendah. 
Rendahnya tingkat penguasaan dan kemampuan berpikir kritis peserta didik di Indonesia salah satunya disebabkan oleh belum optimalnya kualitas pembelajaran yang berlangsung di sekolah maupun perguruan tinggi. IPS merupakan salah satu mata pelajaran di sekolah yang harus menerapkan tingkat penguasaan dan kemampuan berpikiri kritis. Menurut Etin dan Raharjo (2005:15) menyatakan bahwa tujuan dari pendidikan IPS adalah untuk mendidik dan memberi bekal kemampuan dasar kepada peserta didik untuk mengembangkan diri sesuai dengan bakat, minat, kemampuan dan lingkungan serta berbagai bekal siswa untuk melanjutkan pendidikan ke jenjang yang lebih tinggi untuk mencapai tujuan pembelajar IPS di sekolah diperlukan pemilihan model pembelajaran yang sesuai dengan tujuan kurikulum dan kemampuan siswa itu sendiri. Menurut Jarolimek (dalam Etin, 2007:1) bahwa. "Ketepatan guru dalam memilih model pembelajaran akan berpengaruh terhadap keberhasilan siswa.”. Jadi, dalam pelaksanaan pembelajaran IPS harus mencakup tiga aspek utama yaitu, produk, proses dan sikap ilmiah.

Model Pembelajaran Problem Based Learning (PBL) menjadi salah satu solusi untuk dapat memberikan tingkat penguasaan dan kemampuan berpikiri kritis. Keunggulan PBL yaitu pembelajaran yang menggunakan penguasaan kompetensi harus berpusat pada siswa (student centre learning), memberikan pembelajaran dan pengalaman belajar yang relevan serta kontekstual dalam kehidupan. Pembelajarab $P B L$, terutamakan dikembangkan untuk membantu siswa mengembangkan kemampuan berpikir, pemecahan masalah dan keterampilan intelektual. Pembelajaran ini memberikan peluang sebanyak-banyaknya kepada siswa untuk berbagai penemuan, motivasi dan akan terjalinnya kerjasama dalam menyelesaikan tugas. Nurhadi (2003: 55) menyatakan " $P B L$, adalah suatu pembelajaran yang menggunkan masalah sebagai suatu konteks bagi peserta didik untuk untuk belajar tentang cara berpikir kritis dan 
keterampilan pemecahan masalah, serta untuk memperoleh pengetahuan dan konsep esensial dari materi pelajaran"

Berdasarkan observasi di sekolah permasalahan dalam pembelajaran IPS antara lain adalah: (1) Pembelajaran konsep IPS belum dikaitkan dengan kehidupan nyata atau pengalaman siswa sehari-hari sehingga, sulit untuk dipahami peserta didik, (2) Guru tidak menyediakan fasilitas bagi peserta didik untuk mengembangkan strategi permasalahan sesuai dengan cara mereka masing-masing, (3) Dalam pembelajaran IPS guru tidak membiasakan berinteraksi dengan peserta didik dan peserta didik dengan peserta didik, (4) Peserta didik mengalami kebosanan dalam pembelajaran IPS karena materi berpatokan pada buku saja, (5) Peserta didik kurang mampu bersosialisasi dengan lingkungan.

\section{Proses pembelajaran seperti} fenomena di atas yang dilakukan oleh guru, diharapkan terus berlanjut maka dalam proses pembelajaran itu tentunya tidak akan melibatkan peserta didik untuk aktif dalam belajar dan juga tidak akan membiasakan peserta didik untuk berlatih berpikir dalam memecahkan masalah. Sebagaimana kita mengetahui bahwa pembelajaran IPS perlu diaplikasikan dalam kehidupan bermasyarakat, sementara di masyarakat banyak masalah yang harus dipecahkan untuk itulah peserta didik harus dibiasakan untuk mengatasi masalah.

\section{HAKIKAT}

MODEL PEMBELAJARAN PROBLEM

\section{BASED LEARNING (PBL)}

\section{Problem Based Learning} merupakan singkatan dari PBL. Sebuah model pembelajaran yang melibatkan peserta didik untuk memecahkan suatu masalah dan dapat menyelesaikan masalah yang dihadapi sesuai dengan pengetahuan yang mereka miliki dan disertai dengan alasan logis sehingga peserta didik mendapatkan pengalaman belajar melalui kegiatan yang mereka lakukan. Model pembelajaran ini merupakan penggunaan berbagai macam kecerdasan yang diperlukan untuk melakukan konfrontasi terhadap tantangan dunia nyata, 
kemampuan untuk menghadapi segala sesuatu yang baru dan kompleksitas yang ada (Tan, 2004). Masalah-masalah yang dihadapi oleh peserta didik dapat dijadikan sebagai sarana belajar adalah masalah yang memenuhi konteks dunia nyata, yang akrab dengan kehidupan sehari-hari para siswa. Melalui masalah-masalah kontekstual ini para siswa menemukan kembali pengetahuan konsep-konsep dan ide-ide yang esensial dari materi pelajari dan membangunnya ke dalam struktur kognitif. Pembelajaran berbasis masalah ini merupakan suatu pendekatan yang melibatkan pembelajaran dalam investigasi pemecahan, yang mengintegrasikan keterampilan dan konsep dari berbagai konten area (Sudjarat, 2011).

\section{Ciri dan Karakteristik PBL}

Adapun yang menjadi ciri dan karakteristik PBL (Saefuddin dan Berdiati, 2014) sebagai berikut: (1) mengorientasikan siswa kepada masalah autentik dan menghindari pembelajaran terisolasi; (2) erpusat pada siswa dalam jangkwa waktu lama; (3) menciptakan pembelajaran interdisiplin;

(4) penyelidikan masalah autentik yang terintegrasi dengan dunia nyata dan pengalaman praktis; menghasilkan produk/karya dan memamerkannya; (6) mengajarkan kepada siswa untuk mampu menerapkan apa yang mereka pelajari di sekolah dalam kehidupan yang panjang; (7) pembelajaran terjadi pada kelompok kecil (kooperatif); (8) guru berperan sebagai fasilitator, motivator, dan pembimbing;

(9) Masalah diformulasikan untuk memfokuskan dan merangsang pembelajaran; (10) Masalah adalah kendaraan untuk pengembangan keterampilan pemecahan masalah; (11) Informasi baru diperoleh lewat belajar mandiri.

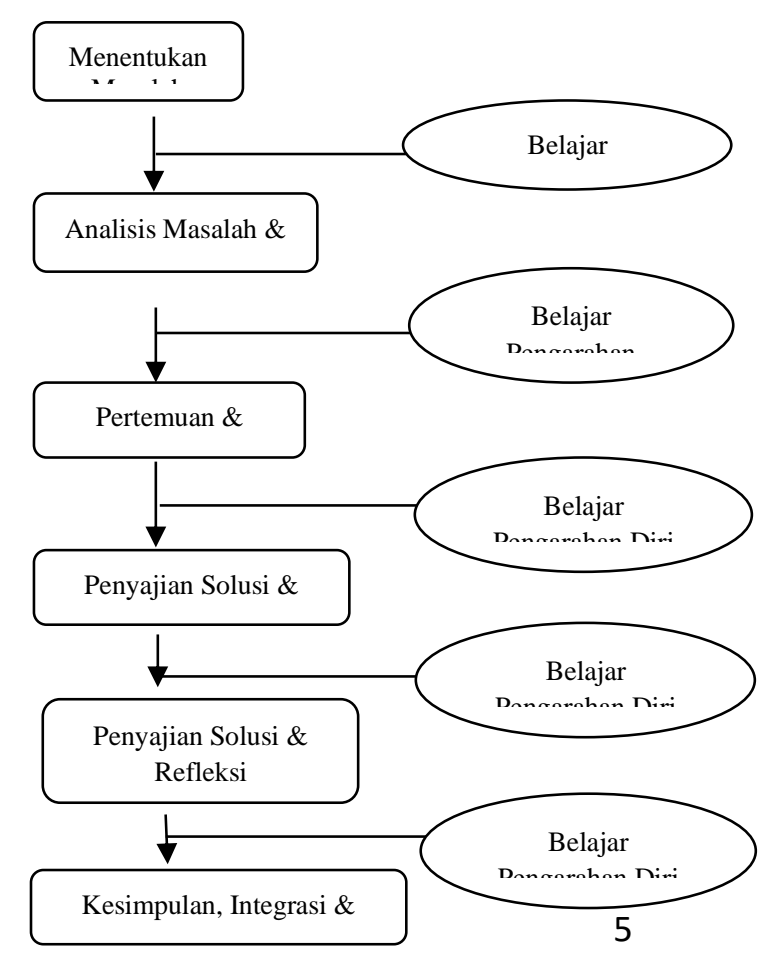


Alur pembelajaran berbasis masalah (Rusman, 2010)

Hubungan pembelajaran berbasis masalah dengan kemampuan berpikr kritis siswa dan hasil belajar siswa yaitu pembelajaran berbasis masalah dapat mengkonstruksi pengetahuan secara bermakna sehingga seiswa terlatih dalam berpikir kritis dalam menganalisis maupun memecahkan suatu permasalahan. Siswa yang berpikir kritis adalah siswa yang mampu mengidentifikasi, mengevaluasi dan mengkonstruksi argumen serta memecahkan masalah dengan tepat (Splitter, 1991). Siswa yang berpikir kritis akan mampu menolong dirinya atau orang lain dalam memecahkan permasalahan yang dihadapi sehingga siswa dapat terlatih mengembangkan daya nalarnya dalam memecahkan permasalahan dan mengaplikasikan konsep-konsep yang telah dipelajari dalam kehidupan nyata. Hal ini tentunya dapat meningkatkan hasil belajar siswa karena siswa dilatih untuk menganalisis, mensistesis dan mengevaluasi suatu informasi, data atau argumen.
2. Kekuatan Problem Based Learning

Adapun kekuatan Promblem Based Learning menurut Paulina (2005:99) sebagai berikut:

a. Fokus pada Kebermaknaan, bukan fakta

Dalam pembelajaran konvensional, ada keharusan mengingat banyaknya informasi dan kemudian mengeluarkan ingatan dalam bentuk ujian. Informasi yang banyak yang disampaikan oleh guru belum tentu semua dapat diserap selama proses pembelajaran terjadi. Hadirnya model Problem Based Learning semata tidak hanya menyajikan informasi untuk diingat siswa tetapi informasi tersabut harus dapat digunakan dalam pemecahan masalah, sehingga terjadi proses kebermaknaan.

b. Meningkatkan Kemampuan Siswa untuk Berinisiatif

Dalam sebuah proses pembelajaran diharapkan siswa aktif dalam mencari sumber informasi untuk mengidentifikasi masalah dan memecahkan masalah sehingga siswa terbiasa untuk berinisiatif dalam 
prosesnya dan pada akhirnya kemampuan mereka akan meningkat.

c. Pengembangan Keterampilan dan Pengetahuan

\section{Penggunaan Problem Based}

Learning oleh guru IPS diharapkan memberi makna yang lebih, contoh nyata penerapan, dan manfaat yang jelas dari materi pelajaran (fakta, konsep, prisip, prosedur). Semakin tinggi tingkat kompleksitas permasalahan yang dituntut untuk mampu memecahkan masalah. Semakin nyata permasalahan, sekmakin tinggi tingkat transferrality dari keterampilan dan pengetahuan siswa ke dalam kehidupan seharihari.

d. Pengembangan Keterampilan Interpersonal dan Dinamika Kelompok

Dengan mewajibkan setiap siswa memiliki Keterampilan interaksi sosial merupakan keterampilan yang amat diperlukan siswa di dalam proses pembelajaran maupun dalam kehidupan sehari-hari. Proses pembelajaran tradisional seringkali menghasilkan keterampilan interaksi sosial karena amat terfokus pada kemampuan bidang ilmu, $P B L$ dapat menyajikan keduanya sekaligus

e. Pengembangan Sikap "Self Motived"

Model pembelajaran Problem

Based Learning yang memberikan kebebasan untuk siswa bereksplorasi karena siswa bereksplorasi bersama siswa lain, dalam bimbingan guru merupakan proses pembelajaran yang disenangi siswa. Dengan situasi belajar yang menyenangkan, siswa akan dengan sendirinya termotivasi untuk belajar terus.

f. Tumbuhnya Hubungan Siswafasilitator (bukan Siswa-guru)

Jika guru sudah mengalami pembelajaran menggunakan Problem Based Learning, biasanya guru akan menyenangi $P B L$, suasana belajar terasa lebih aktif, dinamis, dan berkualitas. Dengan menjadi pembimbing guru dapat menjadi lebih bermanfaat, daripada sekedar penyaji informasi. Hubungan peserta didik dengan guru sebagai fasilitator yang terjadi dalam Problem Based Learning pada akhirnya dapat menjadi lebih menyenangkan bagi guru maupun peserta didik. 
g. Jenjang Pencapaian Pembelajaran dapat ditingkatkan

Walaupun keluasan materi dan kedalaman materi dibandingkan dengan keragaman keterampilan dan kebermaknaan masih banyak dipertanyakan, proses pembelajaran menggunakan $P B L$ dapat menghasilkan pencapaian peserta didik dalam penguasaan materi yang sama luas dan sama dalamnya dengan pembelajaran tradisional. Belum lagi, keragaman keterampilan dan kebermaknaan yang dapat dicapai oleh peserta didik merupakan nilai tambah pemanfaatan Problem Based Learning.

3. Pelaksanaan Model Problem Based Learning

\section{a. Tahap Pembelajaran Problem Based Learning}

Selain memiliki kekuatan seperti yang disebutkan di atas, model pembelajaran PBL juga memiliki tahap-tahap. Menurut Fogarty (Made 2009:92), tahap-tahap model pebelajaran Problem Based Learning adalah sebagai berikut:

menemukan masalah,

mendefenisikan masalah,

mengumpulkan penyelidikan, menyusun hipotesis, (5) melakukan penyelidikan, (6) menyempurnakan permasalahan yang telah didefenisikan, (6) menyempurnakan permasalahan yang telah didefenisikan, (7) menyimpulkan alternatif pemecahan secara kolaboratif, (8) melakukan pengujian hasil (solusi) pemecahan masalah.

b. Penerapan Model Problem Based Learning dalam Proses Pembelajaran IPS di Sekolah

Secara operasional kegiatan guru dan siswa selama proses pembelajaran dapat dijabarkan sebagai berikut:

\begin{tabular}{|c|c|c|c|}
\hline $\begin{array}{l}\mathrm{N} \\
\mathrm{o}\end{array}$ & $\begin{array}{c}\text { Tahap } \\
\text { pembelajara } \\
\mathrm{n}\end{array}$ & $\begin{array}{l}\text { Kegiatan } \\
\text { guru }\end{array}$ & Kegiatan siswa \\
\hline 1 & $\begin{array}{l}\text { Menemukan } \\
\text { masalah }\end{array}$ & $\begin{array}{l}\text { Mengangk } \\
\text { at masalah } \\
\text { yang } \\
\text { terjadi dari } \\
\text { kehidupan } \\
\text { sehari-hari } \\
\text { siswa. } \\
\text { Masalah } \\
\text { yang } \\
\text { diberikan } \\
\text { bersifat } \\
\text { tidak } \\
\text { terdefenisi } \\
\text { kan } \\
\text { dengan } \\
\text { jelas. }\end{array}$ & $\begin{array}{l}\text { Menemukan } \\
\text { masalah dengan } \\
\text { cara melakukan } \\
\text { kajian dan } \\
\text { analisis secara } \\
\text { cermat terhadap } \\
\text { permasalahan } \\
\text { yang diberikan } \\
\text { oleh guru }\end{array}$ \\
\hline 2 & $\begin{array}{l}\text { Mendefenisi } \\
\text { kan Masalah }\end{array}$ & $\begin{array}{l}\text { Mendoron } \\
\mathrm{g} \text { dan } \\
\text { membimbi } \\
\text { ng siswa } \\
\text { untuk } \\
\text { mengguna } \\
\text { kan } \\
\text { kecerdasa } \\
\mathrm{n} \\
\text { interperso } \\
\text { nal dan } \\
\text { kemampua }\end{array}$ & $\begin{array}{l}\text { Dengan } \\
\text { menggunakan } \\
\text { kecerdasan } \\
\text { interpersonal } \\
\text { dan kemampuan } \\
\text { awal berusaha } \\
\text { memahami } \\
\text { masalah. }\end{array}$ \\
\hline
\end{tabular}




\begin{tabular}{|c|c|c|c|}
\hline & & $\begin{array}{l}\mathrm{n} \quad \text { awal } \\
\text { untuk } \\
\text { memaham } \\
\text { i masalah }\end{array}$ & \\
\hline & & $\begin{array}{l}\text { Membimb } \\
\text { ing siswa } \\
\text { secara } \\
\text { bertahap } \\
\text { untuk } \\
\text { mendefeni } \\
\text { sikan } \\
\text { masalah } \\
\end{array}$ & $\begin{array}{l}\text { Berusaha } \\
\text { mendefenisikan } \\
\text { permasalahan } \\
\text { dengan } \\
\text { menggunakan } \\
\text { parameter yang } \\
\text { jelas. }\end{array}$ \\
\hline \multirow[t]{4}{*}{3} & $\begin{array}{l}\text { Mengumpul } \\
\text { kan Fakta }\end{array}$ & $\begin{array}{l}\text { Membimb } \\
\text { ing siswa } \\
\text { untuk } \\
\text { melakukan } \\
\text { pengumpu } \\
\text { lan }\end{array}$ & $\begin{array}{l}\text { Melakukan } \\
\text { pengumpulan } \\
\text { fakta dengan } \\
\text { menggunakan } \\
\text { pengalaman- } \\
\text { pengalaman } \\
\text { yang sudah } \\
\text { diperolehnya }\end{array}$ \\
\hline & & $\begin{array}{l}\text { Membimb } \\
\text { ing siswa } \\
\text { melakukan } \\
\text { pencarian } \\
\text { informasi } \\
\text { dengan } \\
\text { berbagai } \\
\text { cara/meto } \\
\text { de }\end{array}$ & $\begin{array}{l}\text { Melakukan } \\
\text { pencarian } \\
\text { informasi } \\
\text { dengan berbagai } \\
\text { cara serta } \\
\text { dengan } \\
\text { menggunakan } \\
\text { kecerdasarn } \\
\text { majemuk yang } \\
\text { dimiliki }\end{array}$ \\
\hline & & $\begin{array}{l}\text { Membimb } \\
\text { ing siswa } \\
\text { melakukan } \\
\text { pengelolaa } \\
\mathrm{n} \\
\text { informasi }\end{array}$ & $\begin{array}{l}\text { Melakukan } \\
\text { pengelolaan/pen } \\
\text { gaturan } \\
\text { informasi yang } \\
\text { telah diperoleh } \\
\text { dengan } \\
\text { berpatokan } \\
\text { pada: } \\
\text { a. know, } \\
\text { yaitu } \\
\text { informasi } \\
\text { apa yang } \\
\text { diketahui, } \\
\text { need to } \\
\text { know, } \\
\text { yaitu } \\
\text { informasi } \\
\text { apa yang } \\
\text { dibutuhkan } \\
\text { need to do, } \\
\text { c. apa yang } \\
\text { akan } \\
\text { dilakukan }\end{array}$ \\
\hline & $\begin{array}{l}\text { Tahap } \\
\text { Pembelajara } \\
\mathrm{n}\end{array}$ & $\begin{array}{l}\text { Kegiatan } \\
\text { Guru }\end{array}$ & Kegiatan Siswa \\
\hline \multirow[t]{2}{*}{4} & $\begin{array}{l}\text { Menyusun } \\
\text { Hipotesis } \\
\text { (dugaan } \\
\text { sementara) }\end{array}$ & $\begin{array}{l}\text { Membing } \\
\text { siswa } \\
\text { untuk } \\
\text { menysusu } \\
\mathrm{n} \text { hipotesis } \\
\text { terhadap } \\
\text { permasala } \\
\text { han }\end{array}$ & $\begin{array}{l}\text { Membuat } \\
\text { hubungan- } \\
\text { hubungan antar } \\
\text { berbagai fakta } \\
\text { yang ada }\end{array}$ \\
\hline & & $\begin{array}{l}\text { Membimb } \\
\text { ing siswa } \\
\text { untuk } \\
\text { mengguna } \\
\text { kan }\end{array}$ & $\begin{array}{l}\text { Menggunakan } \\
\text { berbagai } \\
\text { kecerdasan } \\
\text { majemuk untuk }\end{array}$ \\
\hline
\end{tabular}

\begin{tabular}{|c|c|c|c|}
\hline & & $\begin{array}{l}\text { kecerdasa } \\
\mathrm{n} \text { majemuk } \\
\text { dalam } \\
\text { menyusun } \\
\text { hipotesis } \\
\end{array}$ & $\begin{array}{l}\text { menyusun } \\
\text { hipotesis }\end{array}$ \\
\hline & & $\begin{array}{l}\text { Membimb } \\
\text { ing siswa } \\
\text { untuk } \\
\text { menyusun } \\
\text { alternatif } \\
\text { jawaban } \\
\text { sementara }\end{array}$ & $\begin{array}{l}\text { Berusaha } \\
\text { menyusun } \\
\text { beberapa } \\
\text { jawaban } \\
\text { sementara }\end{array}$ \\
\hline \multirow[t]{2}{*}{5} & $\begin{array}{l}\text { Melakukan } \\
\text { penyelidika } \\
\mathrm{n}\end{array}$ & $\begin{array}{l}\text { Membimb } \\
\text { ing siswa } \\
\text { untuk } \\
\text { melakukan } \\
\text { penyelidik } \\
\text { an } \\
\text { terhadap } \\
\text { informasi } \\
\text { dan data } \\
\text { yang telah } \\
\text { diperolehn } \\
\text { ya } \\
\end{array}$ & $\begin{array}{l}\text { Melakukan } \\
\text { penyelidikan } \\
\text { terhadap data } \\
\text { dan informasi } \\
\text { yang telah } \\
\text { diperoleh }\end{array}$ \\
\hline & & $\begin{array}{l}\text { Dalam } \\
\text { membimbi } \\
\text { ng siswa } \\
\text { melakukan } \\
\text { penyelidik } \\
\text { an, guru } \\
\text { membuat } \\
\text { struktur } \\
\text { belajar } \\
\text { yang } \\
\text { memungki } \\
\text { nkan siswa } \\
\text { dapat } \\
\text { mengguna } \\
\text { kan } \\
\text { berbagai } \\
\text { cara untuk } \\
\text { mengetahu } \\
\text { i dan } \\
\text { memaham } \\
\text { i dunianya }\end{array}$ & $\begin{array}{l}\text { Dalam } \\
\text { melakukan } \\
\text { penyelidkan } \\
\text { siswa } \\
\text { menggunakan } \\
\text { kecerdasan } \\
\text { majemuk yang } \\
\text { dimilikinya } \\
\text { untuk dan } \\
\text { memahami dak } \\
\text { member makna } \\
\text { data dan } \\
\text { informasi yang } \\
\text { ada }\end{array}$ \\
\hline 6 & $\begin{array}{l}\text { Menyempur } \\
\text { nakan } \\
\text { permasalaha } \\
\mathrm{n} \text { yang telah } \\
\text { didefenisika } \\
\mathrm{n}\end{array}$ & $\begin{array}{l}\text { Membimb } \\
\text { ing siswa } \\
\text { melakukan } \\
\text { penyempu } \\
\text { rnaan } \\
\text { terhadap } \\
\text { masalah } \\
\text { yang telah } \\
\text { didefenisi } \\
\text { kan } \\
\end{array}$ & $\begin{array}{l}\text { Melakukan } \\
\text { penyempurnaan } \\
\text { masalah yang } \\
\text { telah } \\
\text { dirumuskan }\end{array}$ \\
\hline 7 & $\begin{array}{l}\text { Menyimpul } \\
\text { kan } \\
\text { alternatif } \\
\text { pemecahan } \\
\text { masalah } \\
\text { secara } \\
\text { kolaboratif }\end{array}$ & $\begin{array}{l}\text { Membimb } \\
\text { ing siswa } \\
\text { untuk } \\
\text { menyimpu } \\
\text { lkan } \\
\text { alternatif } \\
\text { pemecaha } \\
\text { n masalah } \\
\text { secara } \\
\text { kolaboratif }\end{array}$ & $\begin{array}{l}\text { Membuat } \\
\text { kesimpulan } \\
\text { alternative } \\
\text { pemecahan } \\
\text { masalah secara } \\
\text { kolaboratif }\end{array}$ \\
\hline 8 & $\begin{array}{l}\text { Melakukan } \\
\text { pengujian } \\
\text { hasil } \\
\text { (solusi) } \\
\end{array}$ & $\begin{array}{l}\text { Membimb } \\
\text { ing siswa } \\
\text { melakukan } \\
\text { pengujian }\end{array}$ & $\begin{array}{l}\text { Melakukan } \\
\text { pengujian hasil } \\
\text { (solusi) }\end{array}$ \\
\hline
\end{tabular}




\begin{tabular}{|l|l|l|l|}
\hline $\begin{array}{l}\text { pemecahan } \\
\text { masalah }\end{array}$ & $\begin{array}{l}\text { hasil } \\
\text { (solusi) } \\
\text { pemecaha } \\
\text { n masalah }\end{array}$ & $\begin{array}{l}\text { pemecahan } \\
\text { masalah. }\end{array}$ \\
\hline
\end{tabular}

Dengan menerapkan model Problem Based Learning dalam pembelajaran IPS di sekolah salah satu inovasi pembelajaran berbasis karakter dan budaya bangsa. Pada prinsipnya, pembelajaran Problem Based Learning memberikan penekanan pada penanaman nilai moral, nilai sosial budaya dan karakter bangsa kepada siswa.

\section{PENUTUP}

Model Problem Based Learning adalah salah satu model yang harus dimiliki oleh guru IPS. Kemampuan dalam merencanakan, mengadakan dan menggunakan model ini disesuaikan dengan karakteristik materi dan peserta didik yang diampunya akan memberikan dampak yang besar bagi keberhasilan belajar siswa. Problem Based Learning tidak dapat dilakukan secara spontanitas, diperlukan analisis yang komprehensif dengan memperhatikan berbagai aspek yang dapat mempengaruhi keberhasilan pembelajaran. Akhirnya, guru IPS diharapkan mampu mengenal kekuatan setiap model pembelajaran yang digunakan dengan mengantisipasi kelemahan yang timbul apabila model tersebut dimanfaatkan dalam pembelajaran.

\section{DAFTAR PUSTAKA}

Depdiknas. 2006. Kurikulum Tingkat

Satuan Pendidikan. Jakarta: Depdiknas

Etin Solihatin dan Raharjo. 2005. Cooperative Learning Analisis Pembelajaran IPS. Jakarta: Bumi Aksara

Etin Solihatin. 2007. Cooperatve Learning. Jakarta: Bumi Aksara

Masnur Muslich. 2011. Pendidikan Karakter Menjawab Tantangan Krisis Multidimensional. Jakarta: Bumi Aksara

Made Wena. 2009. Strategi Pembelajaran Inovatif Kontemporer. Jakarta: Bumi Aksara 
Nurhadi. (2003). Pembelajaran

Kontekstual dan Penerapannya

dalam KBK. Malang: Universitas

Negeri Malang.

Paulina Panen. 2005.

Konstruktivisme Dalam

Pembelajaran. Jakarta: Universitas

Terbuka

Prayitno dan Afriva Khaidir. 2011.

Model Pendidikan Karakter Cerdas.

Padang: Penerbit dan Percetakan

UNP Press

Pritasari, Ajeng Desi Crisandi. 2011.

Upaya Meningkatkan Kemampuan

Berpikir

Kritis

Siswa Kelas Xl IPA 2 Sekolah

Menengah Atas Negeri Yogyakarta

Pada

Pembelajaran

Matematika

Melalui

Pembelajaran Kooperatif Tipe Group

Investigation (GI). Skripsi.

Universitas negeri

yogyakarta.

Rusma. 2010. Model-model

Pembelajaran: Mengembangkan

Profesionalisme: Guru. Jakarta:

Raja Grafindo Persada
Sudrajat, A. 2011. Pembelajaran

Berdasarkan Masalah. Jakarta:

Rineka Cipta

Saefuddin, A. dan Berdiati, I. 2014.

Pembelajaran Efektif. Bandung:

Rosdakarya

Splitter, L.J., 1991. Critical Thinking:

What, Why, When and How,

Educational Philosophy and

Theory, 23(1): 89-109

Tan, O.S., 2004. Student's Experience in Problem Based Learning: Three Blind Mice Episode or Educational Innovation, Innovation in Education and Teaching International, 41:169184

Undang-Undang No. 20 Tahun 2003 tentang Sistem Pendidikan Nasional Wina Sanjaya. 2008. Strategi Pembelajaran Berorientasi Standar Proses. Jakarta: Kencana Prenada Media Group 